quistador; después la raza que se recobra para arrojar a los colonizadores; luego, los caudillos que se erigen en mandones y aniquilan a sus adversarios políticos. La danza no tiene sino treguas escasas; pausas en las que el aliento se suspende, como la naturaleza que se inmoviliza al acercarse la tempestad.

Un día Bolívar, en los instantes últimos de su vida, le pregunta a su médico:

- ¿Qué ha venido a buscar a este país, doctor?

- La libertad-responde el médico.

- ¿La ha encontrado Ud?

-Sí, mi general.

- Pues, ha sido Ud. más feliz que yo. Vuelva a Francia, adonde le acompañaría con mucho gusto. Aquí hay demasiados canallas.

Son los toques finales de un hombre desencantado y sin esperanza que ve hasta en el postrer instante las figuras de los caudillejos que destrozan su obra y se apoderan de la libertad para prostituirla o encadenarla.

Ahora, a cien años de distancia, se ha celebrado con pompas oficiales la fecha de su muerte. Sólo con pompas oficiales y frías: Bolívar continúa siendo incomprendido...-D O M I N G O M E L F I.

\title{
LAS DOS HERMANAS DE TUNJA
}

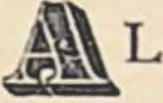

L pie del monumento que rememora la batalla, cerca del puente de Boyacá, esperaban las comisiones; grupos a pie, damitas, jovenes, funcionarios, militares, particulares, estudiantes. Al detenerse el coche, gritos, vivas, saludos; ramos de flores y banderas. En las presentaciones suenan nombres que han sido próceres: Otaloras, Restrepos. En los uniformes, en las maneras cultas de los oficiales, hay una vaga reminiscencia bolivariana. Dirige una joven hermosa, gentil, la reina de los estudiantes tunjenos, la señorita Teresa. Cambian de manos las ofrendas florales y se hace ruedo para iniciar los discursos. Vuelan imágenes atrevidas como las águilas de Boyacá; las frases gallardas rastrean el orgullo adormecido, un hondo sentimiento aviva el dolor de la decadencia con el recuerdo de pretéritas glorias. El viajero, que es recibido como huésped empieza a despertar de la modorra de los largos viajes, se desentume apenas del viento frío en el coche abierto. Quedaron atrás los páramos lluviosos y ahora se ha despejado el cielo; la cla- 
ridad inunda generosa el ambiente, lustra los prados, pone radiación en las corolas. Y sobre la columna y en las lápidas se orean las leyendas heroicas; gritos entusiastas rompen las vibraciones latentes de esos mirajes hechos de viento, vapor y luz. Ondea la bandera de Colombia que toma su ocre al paisaje de las cortadas; irrumpe el color mejicano con su rojo vivo de sangre y su verde de ilusión aplazada. ¡Viva el pensador de América! ¡Viva Colombia! Las manos se buscan, saludan efusivas, los ojos ahondan su mirar, reconociéndose, interrogando la realidad personal para ver si corresponde a la ficción. Fraternidad hispana tiembla en el mismo ambiente en que hace poco más de un siglo se destrozaron las legiones en conflicto desventurado. ¿No lo reconoce así el monumento en la placa que recuerda el aporte de la Legión Británica? Ya desde entonces metidos ellos como una estría que parte el granito aborigen español... Llegan más automóviles, crecen los vivas; la mañana se ha lavado, se ha puesto de gala para el desfile.

Coches embanderados, agrias bocinas y bulliciosos manifestantes van por la carretera moderna, por el lomo de las viejas colinas verdeantes, por el filo de los granitos que sirvieron de pedestal a los guerreros. Por dentro, en el coche del huésped, va la reina estudiantil, blanca, morena, fresca; habla y parece que la menuda lengua tropezase con el paladar tomando acentos como de roce en seda o en terciopelo. Una voz que rompe la indiferencia y penetra como licor suave aromado. La voz anuncia los encantos de Tunja, los arreglos de las fiestas. Al otro lado del huésped conversa también afable el oficial que parece arrancando al cuadro de la vieja batalla boyacense. Por el frente, un enlazamiento de colinas; en los costados, las montañas, en el fondo, las cordilleras. La ruta sube y baja, serpea; de pronto, en uno de los altos, logran los ojos descubrir la ciudad. Se diría un miraje de cuento oriental, Sobre el tapete de las colinas quemadas de sol un agregado de construcciones macizas, aplanadas noblemente como para realzar el hálito de las azoteas y los campanarios. Remates de cúpula $\mathrm{y}$ torre fingen un anhelo pertinaz y colectivo; por la periferia las construcciones se achatan como si volviesen a confundirse con la roca primitiva. Las casas todas se aprietan constituyendo organismo. Los muros son de sillería, sólidos, como para resistir los vientos, los siglos, las revoluciones. 
El hotel de amplios salones da a la plaza. La plaza es vasta, toda empedrada, desolada; un gran cuadrado sin árboles, sin bancos, simple lujo de espacio. Y en los cuatro costados, salvo algún lunar modernoide, casas de largos balcones verdes sobre muros de azul o de blanco. Ventanas enrejadas, celosías y como tapa de pagoda china, largos aleros que rematan la comba de tejados ocres, manchados de lama. A la derecha, una catedral de piedra, pórtico sobrio, de estilo español horriblemente afeada por dentro con unas ojivas de colorete., Al lado de la Catedral una linda casa de estilo tunjeño; larga celosía central y a ambos lados balcones pintados de verde,

Pero hay mucho tesoro escondido que no podría descubrir el viajero en sólo unas horas; por eso las damas solícitas se han of recido a acompañarlo. Una de ellas, Mercedes, hermana de la reina, conversa, explica y orienta a lo largo de las calles que se adornan con la fiesta de las rejas y ondulan, se enlazan por lo alto en la línea irregularmente armoniosa de los tejados. Pasamos la torre cuadrada, torre casi mudéjar de San Ignacio; llegamos a la fachada morisca del antiguo convento de San Francisco; sólidos muros, vanos escasos y nobles; por dentro el claustro, doble arquería en cuadro.

El orgullo de Tunja es la capilla del Rosario, en San Francisco; clásico esplendor iberoamericano, oros radiosos igual que en el tiempo en que incas y aztecas pulimentaban discos imitando al sol; pero enriquecido el alarde con los acantos, las guirnaldas, los capiteles, las espiras salomónicas, los espejos, los óleos ricos de color de los retablos. Altorelieves asombrosos, figuras graves de apóstoles ennoblecidas con mantos de esmaltes en oro, en azul, en rojo; vírgenes de túnicas rosadas, damasquinadas, increíbles; juegos alados de ángeles que se arrancan a la escultura para danzar ritmos audaces, contradictorios, concurrentes como en la sinfonía. Fiesta de colores, gracia de líneas, triunfo de perspectivas, éxtasis y acción; arte cabal, arte teologico; gloria de América. Berruguete y Palestrina realizados en el hábito de una nueva creación. Primitivos y clásicos pierden en un éxtasis la ruta y dejan convertido en oro y en ritmo su clamor; eso es el plateresco, el churriguera en Hispanoamérica.

La guía gentil, Mercedes, muestra tímidamente los tesoros de su ciudad y delante del altar maravilloso aguarda perpleja la impresión del visitante; parece que temiera la incomprensión, la perenne fatiga de los cansados de no ver. Después, la voz femenina empieza a referir circunstancias, explica datos, ayuda a sentir. Un hilo invisible ata la voz melodiosa con los ritmos plásticos, inconsumados de los retablos y parece que 
acabara por darles sonoridad. El anhelo humano se funde en los signos divinos y el milagro de la belleza se consume pleno, misterioso y profundo, fugaz siempre y sin embargo, eterno. Todavía al salir del templo y caminando por las aceras en el atardecer se divisan en la lejanía los azules diáfanos de la meseta y las colinas verdeantes por delante de la cordillera imponente, distante.

Las damas se despiden y una comisión masculina toma a los viajeros para ver de prisa el pozo del cacique indígena; una fuente de aguas abundantes a donde se supone echó los tesoros el último rey aborigen para librarlos del vencedor. También bajo la tarde, ya oscura y lluviosa, se hace la visita de los cojines tallados en lo alto de una roca basáltica, supuesto adoratorio de los indígenas... El huésped no deseaba ver colegios; oyó hablar de un mes de María con ofrendas florales y letanías cantadas y había encargado a sus guías femeninos que lo llevasen. Pensó volver a hallar intacta su infancia envuelta en la infinita, temerosa dulzura del aura materna..., pero prevalecieron los hombres y allá fué, a disgusto, el Instituto. Bajo los aleros de un viejo corredor y en el patio descubierto se agruparon los estudiantes y se produjo el discurso. El discurso sorprendió al huésped y lo arrancó de su desgano y somnolencia. E1 orador juvenil, casi infantil, definió un programa conciso, claro, generoso. Aurora siempre joven a pesar de los siglos que quedan atrás eclipsados cada vez que sale la aurora.

La banda municipal ha ido a tocar galantemente bajo los balcones del huésped. Fl director ha presentado un programa; música extıanjera mala, de segunda, en el país de su origen. Balker y Wolfes y Jones pueden hacer maquinarias, pero hasta ahora todavía no logran rimar sonidos. El huésped indiscreto lo dice y que prefiere algo compuesto por un Gómez o Martínez o González. ¿Qué no saben algo del país? Dudas, perplejidad, demora, pero a poco se inicia la retreta con un bambuco ondulante, sentido, que se llama más o menos: Las Honduras de Tunja. La gente se agolpa alrededor de los músicos; salen al balcón con los obsequiados, las comisiones, las autoridades, las señoras; hay aplausos. ¡Viva Méjico, Viva Colombia! ¡Viva el pensamiento mandando!, grita una voz que parece un eco del anhelo aplastado en Méjico por la brutalidad pretoriana; en el balcón se suceden los discursos, y abajo siguen resonando las muestras de la música nacional. 
La tentación, mientras tanto, conversaba por dentro con el huésped. Y decía: Tengo treinta y cinco años, fuí educado en Oxford y en Cambridge; poseo acciones en la bolsa de Nueva York; setecientos mil dolares en efectivo; una Hacienda en los Llanos; venga conmigo para que vea lo que es entrar mil reses por una dehesa; dormirá usted en una estera con el rifle al lado; pero todo lo que vea en derredor será suyo; de todo lo que tengo la mitad para usted, la mitad para mí; fifíy fifty de todo, véngase amigo. ¿Qué anda haciendo más por el mundo? Cazaremos tigres, comeremos como reyes y hay "chinas» cuantas quiera.... En una canoa larga iremos por los ríos durmiendo bajo el toldo por el rumbo del Amazonas. Allí hay machos, mis sirvientes de un tajo cortan una boa, comen yuca y beben aguardiente. Usted podría escribir allá un libro. Venga, no lo piense; ya le digo, de todo lo que tengo, la mitad. Y mientras esto repite, brillaba inteligencia bajo unos espejuelos claros y las mejillas se acaloran con un whiskey que enseña a beber Oxford. Mal gusto es del whiskey, prefiero el cognac; pero hay nobleza en la cara, en el ademán del propietario colombiano y bajo sus palabras va apareciendo la visión de la selva domeñada, amenazante, fascinante. Tremendo viaje una y otra vez aplazado, pospuesto, irrealizado.

Hubo después esa cosa fea que se llama una conferencia; un orador o varios gritan con una multitud en torno; la expresión se exagera; el pensamiento se diluye o se deforma y la incoherencia alcanza sus mejores éxitos; una impulsión directa que el público recoge y convierte en vibración de conciencia; se produce exaltación.

A las diez empezó el baile, donde la reina; no más de doce parejas. Han reaparecido las jóvenes remozadas, engalanadas en sedas y escotes. La reina está hermosa, muy blanca bajo el negro terciopelo que le ciñe el talle onduloso, juvenil. Una cordial y contagiosa sonrisa consuma presentaciones, enlaza parejas, anima a la danza. La hermana Mercedes también se ha transformado en una nueva belleza entre sedas de rosa; traje ajustado en escultura viviente, palpitante; esbeltez castellana, severa, perfecta, casta. Hay el período en que es posible describir los ojos, el perfil, la boca, pero se llega raras veces a otro estado en el que ni se mira ni se deja de mirar, pero se embebe; igual que una embriaguez que no sólo marea sino que exalta. 
Colma... Se ha decretado el boycot de lo bárbaro, con lo que quedaron proscritas las músicas de marca industrial. Revive el pasillo, juntando, acordando parejas. Se separan, se persiguen, se envuelven los bailadores al ritmo ternario de bambucos y torbellinos. Una alegría desbordada inventa giros, los extrae de la alfombra, del piso. Murillo en el piano impone, revive los aires nativos. Síguelo la orquesta, al principio con timidez, como si no osase ser lo que fué en sus días de señorío, la estirpe hoy humillada; finalmente se entrega y suena como nunca se había logrado: orgullosa, espontánea, dominadora. Los viejos se animan, se levantan, se añaden a las rondas. Mercedes, como su hermana, baila e invita a bailar, quiere que todos estén contentos; juega con el ritmo y con el júbilo. Envuelta en resplandor deslumbra si pasa, y se aleja, y en seguida, en otros casos, cuando sus brazos armoniosos dirigen al torpe bailador, entonces, como el baño de una corriente mansa, pasa el destino hecho licor de ilusión. Suceden a los pasos populares los viejos valses sabrosos, como dicen por allá en que se mece la fantasía. Y a ratos, un rozamiento leve inyecta el ensueño de viva ansiedad, reclamo de venturas positivas. El alto de la orquesta rompe, quiebra, destruye implacablemente, imbécilmente, definitivamente, la posibilidad indudable de dicha.

Una vez roto el círculo mágico de los destinos que buscan alianzas, es imposible recobrar la holgura, la intimidad, la levitación que nos pone fuera del alcance de toda impresión vulgar. El vacío forma huecos en derredor y el mismo pensamiento se ausenta. Luego, una que otra frase trivial y distante, y por fin el ansia de renovar, así sea en cualquier otro plano, la intimidad... ¿Verdad que Tunja vale la pena de ser conocida? Diga usted algo de Tunja; usted que puede hacerse oír ... Sin duda; sí .., pero, me han dicho que usted también escribe; porque no, mejor usted... Sea usted la voz de Tunja

El baile se suspende a intervalos y entonces se reanudan más precisas las conversaciones; circulan, se detienen las parejas; se pasean radiantes las mujeres y entre los grupos se abren paso los mozos que ofrecen en bandejas de plata la champaña que recuerda el culto de Francia en estas antiguas poblaciones del continente ... Hermosa fiesta, exclama el huésped, y su gentil acompañante inquiere: ¿De verdad ha estado contento? Pues eso hemos querido... Quisimos que usted, por unas horas al menos, se olvidara de todas sus contrariedades y se sintiera a gusto, como si estuviese en su casa entre los suyos.... Piensa el huésped: ¿Casa?... Esta, por un instante y bendita... y tornan a envolverse las parejas en los giros de la clásica danza 
en criollo. Al piano, el maestro Murillo ha ido creciendo y está en pleno derroche; vigor, sentimentalismo, infinito sentimiento. La orquesta ebria de ritmo toca marcando exacto, poderoso, el compás... El tiempo se ha ido tragando más horas, se empieza a hacer palpable la conveniencia de las despedidas.. Y todo ocurrí́ como si fuese un sueño. - J O S É V A S C O N C E L O S.

Exclusivo para Atenea en Chile.

\section{DIVAGACIONES ALREDEDOR DE LA POESIA}

\section{VI.-La poesía de hoy. Sus formas}

$15 \mathrm{~N}$

la poesía nueva se distinguen hasta ahora y principalmente, tres formas: el poema de pensamientos asociados, el poema deshumanizante y el poema que intenta, más que otra cosa, valorizarse por la música que resulta de la aproximación de las palabras que, a falta de relaciones lógicas, las tienen de color y de sonido. Esta última forma es la más noble y lá más difícil: es la poesía pura. Continúa en cierto modo y en su parte esencial, la tradición de la más alta poesía de todos los tiempos. Como formas inferiores o menores podríamos citar la de los caligramas y aquella tan socorrida por los poetas runrúnicos: la poesía a base de metáforas, especie de greguerías en verso. Por ejemplo:

la pluma corre sobre los renglones

como los trenes hacia la frontera

al salir del túnel el tren

desata un acordeón aportillado

alguien le dió cuerda el río

para que caminara más rápido

Pérez Santana y Reyes Messa: 12 poemas en un sobre.

Como ejemplo del poema de pensamiento asociados citaremos uno de Cendrars:

... Deshoja la rosa de los vientos

He aquí que zumban las tempestades desencadenadas

Los trenes ruedan en torbellino sobre sus redes 